\section{A Rare Fatal Case of Rectus Hematoma Related to EKOS Treatment in a Patient with Acute Pulmonary Embolism}

\begin{abstract}
Yih-Ying Siow ${ }^{1}$, Nai-Yu Chi ${ }^{1}$, Ho-Ming Su ${ }^{1,2}$ and Po-Chao Hsu ${ }^{1,2 *}$
${ }^{1}$ Division of Cardiology, Department of Internal Medicine, Kaohsiung Medical University Hospital, Kaohsiung Medical University, Kaohsiung, Taiwan
\end{abstract}

${ }^{2}$ Department of Internal Medicine, Faculty of Medicine, School of Medicine, Kaohsiung Medical University, Kaohsiung, Taiwan

\section{Dear Editor}

Pulmonary Embolism (PE) is a life-threatening emergency. Clinical presentation varies from dyspnea to sudden cardiac death [1]. Risk stratification is important for treatment for PE. For high risk patients, reperfusion for obstructive pulmonary artery with thrombolytic therapy is indicated according to current guideline [2]. Endovascular therapy using Catheter-Directed Thrombolysis (CDT) or mechanical thrombectomy is another alternative choice for reperfusion and decrease the bleeding risk of systemic thrombolytic therapy [2]. EkoSonic Endovascular System (EKOS) is a kind of treatment of CDT in combination with high frequency, low power ultrasound energy to achieve clot dissolution. Comparing with traditional CDT, EKOS can decrease the thrombolytic dose and duration of CDT which may further decrease the bleeding risk. Although EKOS is a safe and effective treatment for PE [3-5], it still has the possible risk of major bleeding including Intra-Cranial Hemorrhage (ICH). Rectus hematoma is an extremely rare bleeding complication and seldomly cause mortality. Herein we reported a fatal case of rectus hematoma related to EKOS treatment in a patient with acute PE.

A 77-year-old female suffered from progressive dyspnea was sent to our Emergency Department (ED). Tracing back her history, she was a case of hypertension and old stroke. On arrival at our ED,

*Corresponding author: Po-Chao Hsu, Division of Cardiology, Department of Internal Medicine, Kaohsiung Medical University Hospital, Kaohsiung Medical University, Kaohsiung, Taiwan, Tel: +886 73121101; E-mail: pochao.hsu@gmail. com

Citation: Siow Y-Y, Chi N-Y, Su H-M, Hsu P-C (2021) A Rare Fatal Case of Rectus Hematoma Related to EKOS Treatment in a Patient with Acute Pulmonary Embolism. J Clin Stud Med Case Rep 8: 115.

Received: April 11, 2021; Accepted: April 15, 2021; Published: April 22, 2021

Copyright: (c) 2021 Siow Y-Y, et al. This is an open-access article distributed under the terms of the Creative Commons Attribution License, which permits unrestricted use, distribution, and reproduction in any medium, provided the original author and source are credited. laboratory data showed increased D-Dimer and chest Computed Tomography (CT) revealed pulmonary embolism over right main pulmonary artery (Figure 1A). The patient was then admitted to our cardiac care unit. Due to impending respiratory failure, endovascular therapy with EKOS insertion was performed for further ultrasoundassisted thrombolysis. Initial CDT treatment was smooth and oxygen saturation and hemodynamic became improved under the treatment. However, shock was noted later and vasopressors were used for maintain hemodynamic. Progressive abdominal fullness was also found after shock episode. We arranged emergent abdominal CT and result showed bilateral rectus hematoma (Figures 1B-1D). Because of profound shock and ongoing metabolic acidosis, we removed EKOS catheter and performed blood transfusion for the patient. Unfortunately, shock condition still progressed even under above treatment. Due to high surgical risk under profound shock status, family signed do-not-resuscitate order and patient finally expired.

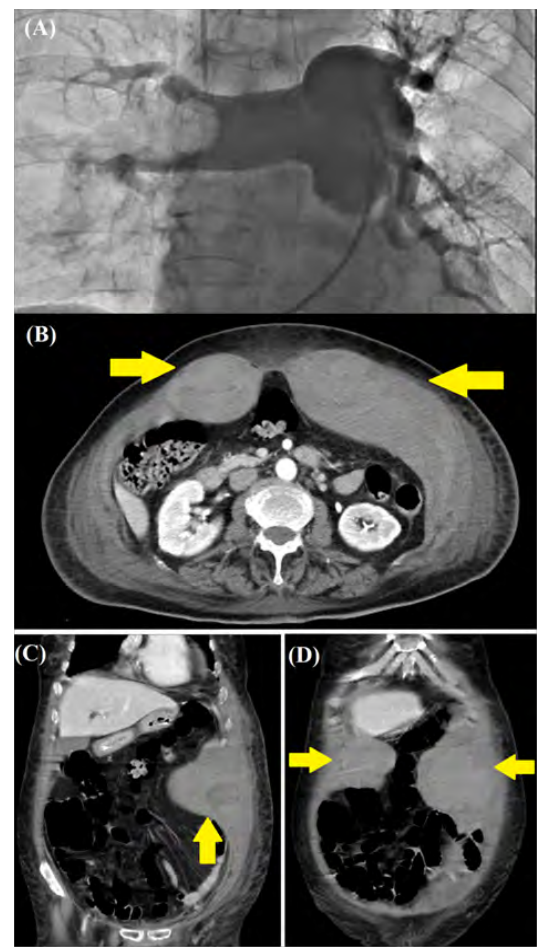

Figure 1: A) Chest computed tomography (CT) revealed pulmonary embolism over right main pulmonary artery; A-D) Abdominal CT showed bilateral rectus hematoma aftershock episode.

EKOS is an FDA-approved device with good efficacy and safety for treatment of PE [3-5]. It may reduce the major bleeding risk than systemic thrombolytic therapy and CDT treatment. However, risk of ICH and other bleeding is still reported in the literature [35]. Rectus hematoma is an extremely rare complication of EKOS 
treatment. Only very limited case was reported but no mortality case was searched under EKOS treatment [5]. To our knowledge, our case might be the first fatal case of rectus hematoma related to EKOS treatment. In our experience of EKOS treatment (around 70 cases) in Kaohsiung medical university hospital, no case of ICH was noted. Besides this case, no other case with mortality was related to bleeding event. Therefore, this rare case reminds physician that despite of good efficacy and safety of EKOS for treatment of PE, we should keep rectus hematoma in mind while using EKOS to decrease and prevent the possible disaster occur.

\section{References}

1. Morrone D, Morrone V (2018) Acute Pulmonary Embolism: Focus on the Clinical Picture. Korean Circ J 48: 365-381.
2. Konstantinides SV, Meyer G, Becattini C, Bueno H, Geersing G-J, et al. (2020) 2019 ESC Guidelines for the diagnosis and management of acute pulmonary embolism developed in collaboration with the European Respiratory Society (ERS). Eur Heart J 41: 543-603.

3. Kennedy RJ, Kenney HH, Dunfee BL (2013) Thrombus resolution and hemodynamic recovery using ultrasound-accelerated thrombolysis in acute pulmonary embolism. J Vasc Interv Radiol 24: 841-848.

4. Mangi MA, Rehman H, Bansal V, Zuberi O (2017) Ultrasound Assisted Catheter-Directed Thrombolysis of Acute Pulmonary Embolism: A Review of Current Literature. Cureus 9: 1492.

5. Lee KA, Cha A, Kumar MH, Rezayat C, Sales CM (2017) Catheter-directed, ultrasound-assisted thrombolysis is a safe and effective treatment for pulmonary embolism, even in high-risk patients. J Vasc Surg Venous Lymphat Disord 5: 165-170. 


\section{Hif}

Advances In Industrial Biotechnology | ISSN: 2639-5665

Advances In Microbiology Research | ISSN: 2689-694X

Archives Of Surgery And Surgical Education | ISSN: 2689-3126

Archives Of Urology

Archives Of Zoological Studies | ISSN: 2640-7779

Current Trends Medical And Biological Engineering

International Journal Of Case Reports And Therapeutic Studies | ISSN: 2689-310X

Journal Of Addiction \& Addictive Disorders | ISSN: 2578-7276

Journal Of Agronomy \& Agricultural Science | ISSN: 2689-8292

Journal Of AIDS Clinical Research \& STDs | ISSN: 2572-7370

Journal Of Alcoholism Drug Abuse \& Substance Dependence | ISSN: 2572-9594

Journal Of Allergy Disorders \& Therapy | ISSN: 2470-749X

Journal Of Alternative Complementary \& Integrative Medicine | ISSN: 2470-7562

Journal Of Alzheimers \& Neurodegenerative Diseases | ISSN: 2572-9608

Journal Of Anesthesia \& Clinical Care | ISSN: 2378-8879

Journal Of Angiology \& Vascular Surgery | ISSN: 2572-7397

Journal Of Animal Research \& Veterinary Science | ISSN: 2639-375

Journal Of Aquaculture \& Fisheries | ISSN: 2576-5523

Journal Of Atmospheric \& Earth Sciences | ISSN: 2689-8780

Journal Of Biotech Research \& Biochemistry

Journal Of Brain \& Neuroscience Research

Journal Of Cancer Biology \& Treatment | ISSN: 2470-7546

Journal Of Cardiology Study \& Research | ISSN: 2640-768X

Journal Of Cell Biology \& Cell Metabolism | ISSN: 2381-1943

Journal Of Clinical Dermatology \& Therapy | ISSN: 2378-8771

Journal Of Clinical Immunology \& Immunotherapy | ISSN: 2378-8844

Journal Of Clinical Studies \& Medical Case Reports | ISSN: 2378-880

Journal Of Community Medicine \& Public Health Care | ISSN: 2381-1978

Journal Of Cytology \& Tissue Biology | ISSN: 2378-9107

Journal Of Dairy Research \& Technology | ISSN: 2688-9315

Journal Of Dentistry Oral Health \& Cosmesis | ISSN: 2473-6783

Journal Of Diabetes \& Metabolic Disorders | ISSN: 2381-201X

Journal Of Emergency Medicine Trauma \& Surgical Care | ISSN: 2378-8798

Journal Of Environmental Science Current Research | ISSN: 2643-5020

Journal Of Food Science \& Nutrition | ISSN: 2470-1076

Journal Of Forensic Legal \& Investigative Sciences | ISSN: 2473-733X

Journal Of Gastroenterology \& Hepatology Research | ISSN: 2574-2566
Journal Of Genetics \& Genomic Sciences | ISSN: 2574-2485

Journal Of Gerontology \& Geriatric Medicine | ISSN: 2381-8662

Journal Of Hematology Blood Transfusion \& Disorders | ISSN: 2572-2999

Journal Of Hospice \& Palliative Medical Care

Journal Of Human Endocrinology | ISSN: 2572-9640

Journal Of Infectious \& Non Infectious Diseases | ISSN: 2381-8654

Journal Of Internal Medicine \& Primary Healthcare | ISSN: 2574-2493

Journal Of Light \& Laser Current Trends

Journal Of Medicine Study \& Research | ISSN: 2639-5657

Journal Of Modern Chemical Sciences

Journal Of Nanotechnology Nanomedicine \& Nanobiotechnology | ISSN: 2381-2044

Journal Of Neonatology \& Clinical Pediatrics | ISSN: 2378-878X

Journal Of Nephrology \& Renal Therapy | ISSN: 2473-7313

Journal Of Non Invasive Vascular Investigation | ISSN: 2572-7400

Journal Of Nuclear Medicine Radiology \& Radiation Therapy | ISSN: 2572-7419

Journal Of Obesity \& Weight Loss | ISSN: 2473-7372

Journal Of Ophthalmology \& Clinical Research | ISSN: 2378-8887

Journal Of Orthopedic Research \& Physiotherapy | ISSN: 2381-2052

Journal Of Otolaryngology Head \& Neck Surgery | ISSN: 2573-010X

Journal Of Pathology Clinical \& Medical Research

Journal Of Pharmacology Pharmaceutics \& Pharmacovigilance | ISSN: 2639-5649

Journal Of Physical Medicine Rehabilitation \& Disabilities | ISSN: 2381-8670

Journal Of Plant Science Current Research | ISSN: 2639-3743

Journal Of Practical \& Professional Nursing | ISSN: 2639-568

Journal Of Protein Research \& Bioinformatics

Journal Of Psychiatry Depression \& Anxiety | ISSN: 2573-0150

Journal Of Pulmonary Medicine \& Respiratory Research | ISSN: 2573-0177

Journal Of Reproductive Medicine Gynaecology \& Obstetrics | ISSN: 2574-2574

Journal Of Stem Cells Research Development \& Therapy | ISSN: 2381-2060

Journal Of Surgery Current Trends \& Innovations | ISSN: 2578-7284

Journal Of Toxicology Current Research | ISSN: 2639-3735

Journal Of Translational Science And Research

Journal Of Vaccines Research \& Vaccination | ISSN: 2573-0193

Journal Of Virology \& Antivirals

Sports Medicine And Injury Care Journal | ISSN: 2689-8829

Trends In Anatomy \& Physiology | ISSN: 2640-7752

Submit Your Manuscript: https://www.heraldopenaccess.us/submit-manuscript 